\title{
Pengembangan Media Game Edukasi Adventure Cooking untuk Meningkatkan Perilaku Prososial Anak Usia Dini
}

\author{
Rizki Amalia ${ }^{1 凶}$, Zarina Akbar $^{1}$, Yuliani Nurani ${ }^{1}$ \\ Pendidikan Anak Usia Dini, Universitas Negeri Jakarta, Indonesia(1) \\ DOI: $10.31004 /$ obsesi.v6i3.1697
}

\begin{abstract}
Abstrak
Penelitian ini berawal dari hasil observasi awal yang dilakukan, perilaku prososial anak di sekolah TK Dharma Wanita PDAM Tirta Musi Palembang masih rendah, yang dikarenakan minimnya media penunjang dalam mengembangkan perilaku prososial anak. Berdasarkan temuan tersebut, dilakukan penelitian yang bertujuan untuk mengembangkan media game edukasi Adventure cooking untuk meningkatkan perilaku prososial anak. Metode penelitian ini menggunakan metode penelitian dan pengembangan (research and development) dengan model ADDIE. Data perkembangan perilaku prososial yang diperoleh pada penelitian ini dari hasil observasi. Game ini telah diuji cobakan pada anak usia 5-6 tahun. Hasil penelitian ini menunjukkan bahwa terjadi peningkatan perilaku prososial anak dengan persentase rata-rata sebesar 31\% setelah anak menggunakan media game edukasi Adventure cooking.
\end{abstract}

Kata Kunci: game edukasi; prilaku prososial; media pembelajaran.

\begin{abstract}
This research started from the results of initial observations, the prosocial behavior of children in the Dharma Wanita Kindergarten PDAM Tirta Musi Palembang was still low, which was due to the lack of supporting media in developing children's prosocial behavior. Based on these findings, a study was conducted that aims to develop an educational game media for Adventure Cooking to improve children's prosocial behavior. This research method uses research and development methods with the ADDIE model. The data on the development of prosocial behavior obtained in this study were from observations. This game has been tested on children aged 5-6 years. The results of this study indicate that there is an increase in children's prosocial behavior with an average percentage of $31 \%$ after children use Adventure Cooking educational game media.
\end{abstract}

Keywords: educational game; prosocial behavior; learning media.

Copyright (c) 2021 Rizki Amalia, et al.

$\triangle$ Corresponding author:

Email Address: rizkiamalia809@gmail.com (Jakarta, Indonesia)

Received 29 May 2021, Accepted 23 August 2021, Published 29 August 2021 


\section{PENDAHULUAN}

Sebagian besar pendidikan lebih memperhatikan aspek perkembangan intelektual anak, namun mengabaikan aspek perkembangan lainnya seperti aspek perkembangan sosial. Aspek perkembangan sosial dirasa sangat penting, karena pada hakikatnya manusia merupakan makhluk sosial yang membutuhkan manusia lainnya dalam kehidupannya sehari-hari. Seperti yang dikatakan Goleman (2018:44) bahwa hanya sekitar 20\% saja kesuksesan seseorang ditentukan oleh faktor IQ. Sisanya sebanyak $80 \%$ ditentukan oleh faktor lain. Salah satu aspek perkembangan sosial adalah perilaku prososial. Eisenberg dkk., (2015) mendefinisikan perilaku prososial adalah perilaku sukarela yang termotivasi dari dalam dari sendiri untuk memberikan manfaat bagi orang lain, tindakan ini dimotivasi oleh kepedulian terhadap orang lain ataupun oleh nilai-nilai, tujuan, dan penghargaan diri yang diinternalisasi daripada dengan harapan imbalan yang nyata atau sosial atau penghindaran hukuman. Griese dan Buhs (Griese dan Buhs, 2014; Woods dkk., 2016) juga mendefinisikan mengenai perilaku prososial yang merupakan perilaku sosial sukarela yang bertujuan untuk membantu orang lain, perilaku ini termasuk berbagi, membantu, menghibur, dan mendukung orang lain. Selanjutnya Sette dkk., (2018) mengatakan bahwa perilaku prososial merupakan suatu tindakan sukarela dan disengaja yang bertujuan untuk memberi manfaat kepada orang lain. Selanjutnya menurut Thijssen dkk., (2015) perilaku prososial sangat berperan penting dalam membangun dan menjalin hubungan dengan orang lain. Hal ini dikarenakan setiap manusia dalam kesehariannya akan bertemu dengan banyak orang, menjalin dan membina hubungan sosial antarmanusia. Untuk menjalin hubungan yang harmonis tersebut sangat diperlukan perilaku prososial.

Sangat penting untuk mengajarkan anak perilaku prososial sejak dini. Keterlibatan dalam perilaku prososial pada usia kanak-kanak merupakan prediksi keterlibatan prososial pada usia dewasa nantinya (Eisenberg dkk., 1999; Spivak dan Farran, 2012). Selain itu, kecenderungan prososial pada anak-anak memiliki hubungan yang positif dengan penerimaan teman sebaya dan prestasi akademik (Layous dkk., 2012; Thijssen dkk., 2015). Semakin memperjelas bahwa perilaku prososial anak seharusnya sangat diperhatikan perkembangannya. Fakta yang terjadi dilapangan menunjukkan bahwa perilaku prososial pada anak usia dini masih rendah. Berdasarkan hasil studi pendahuluan yang dilakukan penulis di salah satu TK Dharma Wanita PDAM Tirta Musi Palembang, terlihat bahwa dalam aspek menolong dari 17 orang anak, hanya dua orang anak (12\%) saja yang skornya berkembang sesuai harapan (BSH), sedangkan 15 orang anak lainnya (88\%) masih berkembang (MB). Pada aspek empati, dari 17 orang anak hanya empat orang anak (24\%) yang mendapat skor berkembang sesuai harapan (BSH), sedangkan 13 orang lainnya (76\%) masih berkembang (MB). Untuk aspek kerjasama, dari 17 orang anak hanya lima orang anak $(30 \%)$ yang skornya berkembang sesuai harapan, 12 orang lainnya (70\%) masih berkembang (MB).

Selain itu peneliti lain juga menemukan masalah yang sama dengan penulis, seperti penelitian yang dilakukan oleh Drupadi dkk., (2014) bahwa kurang tampaknya perilaku prososial ini terlihat pada perilaku anak yang kurang mau berbagi misalnya mainan, bekal makanan, anak sering mengolok-olok, maupun mengejek dengan kata-kata "cengeng" kepada temannya yang menangis ketika jatuh dari pada menolongnya. Kegiatan pembelajaran lebih banyak dilakukan secara individu. Hal ini terlihat selama kegiatan observasi dilakukan, tidak ada kegiatan pembelajaran secara berkelompok. Selain itu, media pembelajaran yang digunakan untuk mengembangkan perilaku prososial di sekolah hanyalah dengan menggunakan media buku cerita. Guru belum memiliki media pembelajaran khusus untuk mengenalkan perilaku prososial pada anak. Perilaku prososial hanya diajarkan pada anak dengan menggunakan bantuan media buku cerita. Pembelajaran menggunakan media buku cerita juga tidak dilakukan secara efektif mengingat buku cerita yang mengajarkan perilaku prososial hanya ada enam buku saja. 
Pada era serba modern ini, guru harus dapat beradaptasi dengan perkembangan teknologi yang ada. Selain itu guru harus memiliki kompetensi profesional salah satunya adalah mampu mengembangkan kurikulum dan pembelajaran secara kreatif dan inovatif (Maswan dan Muslimin, 2017). Diharapkan para guru dapat mengembangkan pola pembelajaran yang lebih bervariasi untuk menarik minat belajar anak. Melalui media komputer pendidik dapat membuat berbagai macam media pembelajaran seperti drills and practice, tutorial, simulasi, permainan dan discovery (Arsyad, 2014:55). Salah satu jenis pengembangan media pembelajaran melalui komputer yang sedang booming saat ini adalah game edukasi.

Media pembelajaran game edukasi termasuk dalam multimedia interaktif. Game sendiri didefinisikan sebagai latihan yang dilakukan secara sukarela dimana terdapat persaingan antar pemain yang dibatasi oleh berbagai aturan sehingga nantinya akan menghasilkan hasil yang tidak seimbang (Avedon dan Smith, 1971; Schell, 2008). Game edukasi termasuk salah satu jenis game. Jenis game edukasi ini mengacu pada isi dan tujuan game yang tujuan utama dari game ini untuk memancing minat belajar sambil bermain (Aeni, 2009). Menurut Mubarok (2018) game edukasi adalah sebuah permainan yang dijadikan sebagai media dalam menunjang proses pembelajaran, yang mengandung unsur mendidik atau nilai-nilai pendidikan. Pendapat lain oleh Chagas dkk., (2018) bahwa game yang dirancang untuk meningkatkan keterampilan kognitif dan intelektual orang disebut game edukasi, game pembelajaran, atau game serius. Game dapat dibuat dengan berbagai tema. Salah satunya adalah game dengan mengusung tema petualangan. Pendapat dari Rifqiana dkk., (2018) game petualangan (adventure) merupakan program software yang mempresentasikan lingkungan tiruan dimana pemain akan berinteraksi untuk memecahkan masalah yang ada dalam permainan tersebut dan pemain seolah-olah berperan sebagai seorang tokoh dalam lingkungan game tersebut. Menurut Anggraini, Erviana, Anggraini, \& Prasetya (2016) game petualangan (adventure) menekankan pada penyelesaian jalan cerita, dimana pemain akan diminta memecahkan teka-teki ataupun menyimpulkan rangkaian peristiwa karakter hingga penggunaan benda-benda pada tempat yang sesuai. Game yang akan dibuat berganre adventure games, dimana game petualangan merupakan game yang dimana pemainnya harus menyelesaikan sejumlah tes untuk maju melalui dunia pada tahap berikutnya (Gros, 2007; Hong dkk., 2009).

Selain itu Herminastiti (2019) mengatakan bahwa memasak merupakan serangkaian kegiatan dimulai dari mempersiapkan bahan, peralatan yang digunakan, sampai proses pengolahan sampai bahan makanan siap untuk di makan. Pendapat lain mengatakan bahwa memasak merupakan suatu proses pemberian panas (application of head) pada bahan masakan sehingga bahan tersebut dapat dimakan (eatable), lezat dilidah (palatable), aman dimakan (safer to eat), mudah dicerna (digestible), dan berubah penampilannya (change its appearance) (Ceserani dkk., 1982; Bartono, 2009; Syahrizal dan Putri, 2014). Sehingga dapat disintesiskan bahwa Game Edukasi Adventure Cooking adalah suatu permainan yang dirancang khusus untuk melatih perilaku sosial pemainnya dimana pemain harus menyelesaikan misi membuat suatu masakan kesukaan kerakter keluarga mulai dari kegiatan mempersiapkan bahan, peralatan yang digunakan, sampai proses pengolahan sampai bahan makanan siap untuk di makan. Sesuai dengan namanya, game edukasi ini berfungsi untuk membantu proses kegiatan pembelajaran yang dirancang sedemikian rupa menjadi sebuah game atau permainan yang dapat dimainkan oleh anak. Program multimedia berformat game edukasi memunculkan aktivitas belajar sambil bermain, sehingga siswa tidak merasa bahwa mereka sesungguhnya sedang belajar (Basri, 2015:20). Game edukasi ini dipandang memiliki banyak kelebihan untuk meningkatkan berbagai kemampuan anak tetapi tidak membuat anak merasakan bahwa mereka sedang belajar dengan memainkan game tersebut. Hal inilah yang menjadi salah satu alasan penulis untuk mengembangkan media game edukasi untuk meningkatkan perilaku prososial anak. 
Sebelumnya Hong dkk., (2014) telah mengembangkan sebuah game digital edukasi untuk anak usia dini yang disebut dengan "Embodied Interactive Video Game (EIVG)". Game ini dimainkan oleh seorang anak, dimana anak harus menyelesaikan berbagai tantangan dalam game ini. Tantangan pertama adalah mengidentifikasi sifat-sifat objek, Tantangan berikutnya adalah mengidentifikasi atribut dari objek dan memasukkannya ke keranjang rahasia di bagian bawah layar sesuai dengan atribut mereka dengan cara melambaikan tangan. Selain itu, telah ada penelitian yang menggunakan game edukasi berbasis digital yang dilakukan oleh Mubarok (2018) yang diberi nama game edukasi "Ayo Memasak". Game yang dikembangkan ini digunakan untuk meningkatkan kemampuan kognitif anak serta untuk memberikan pengetahuan baru pada anak mengenai makanan sehat.

Kedua game di atas memiliki persamaan yaitu dimainkan oleh satu orang anak saja. Berbeda halnya dengan game yang akan dikembangkan dalam penelitian ini, yaitu game Adventure Cooking yang akan dimainkan secara berkelompok oleh anak. Dibuatnya konsep game berkelompok ini, terkait dengan tujuan dalam pembuatan game ini yaitu untuk meningkatkan perilaku prososial anak. Hal ini sesuai dengan yang dikatakan Kostelnik dkk., (2012) bahwa salah satu aspek perilaku prososial adalah dengan bekerjasama. Sehingga untuk menciptakan suatu kerjasama antaranak haruslah dibuat rancangan game yang dimainkan secara berkelompok. Anak harus bekerjasama untuk menyelesaikan tantangan di dalam game ini, yaitu membuat makanan untuk karakter keluarga yaitu, ayah, ibu, kakak, adik, kakek dan nenek. Game ini merupakan bentuk digital dari kegiatan fun cooking, dan salah satu manfaat kegiatan fun cooking adalah untuk menstimulasi keterampilan sosial anak seperti kerja sama dan komunikasi yang dapat dilakukan anak selama kegiatan memasak (Mayeski, 2002; Mirawati dkk., 2018). Namun, kegiatan fun cooking memiliki kelemahan seperti terlalu banyak alat dan bahan yang digunakan, sehingga penulis ingin membuat suatu game edukasi yang tetap dapat memberikan manfaat yang sama seperti kegiatan fun cooking terutama untuk meningkatkan perilaku prososial anak seperti menolong, berbagi, kerjasama dan empati.

Berdasarkan penelitian relevan dan kenyataan yang ditemukan, semakin menarik perhatian penulis untuk mengembangkan sebuah game edukasi untuk mengoptimalkan perilaku prososial anak usia dini. Pada penelitian ini terdapat beberapa kebaruan yaitu: 1 . Pada penelitian sebelumnya, media game edukasi dirancang untuk meningkatkan kemampuan kognitif anak sedangkan penelitian ini merupakan sebuah media game edukasi yang akan diberi nama Adventure Cooking yang dirancang untuk mengoptimalkan perilaku prososial pada anak; kemudian 2. Pada penelitian sebelumnya, tidak menggunakan sistem waktu, sedangkan pada penelitian ini game yang dibuat menggunakan sistem waktu dimana akan ada alarm yang berbunyi saat hendak berganti pemain dalam satu kelompok bermain; dan 3. Game yang dibuat oleh peneliti sebelumnya hanya dimainkan oleh satu anak saja, sedangkan pada penelitian ini game dirancang untuk dimainkan secara berkelompok.

\section{METODOLOGI}

Penelitian ini mengembangkan produk berupa media game edukasi Adventure Cooking untuk meningkatkan perilaku prososial anak usia 5-6 tahun di Kota Palembang. Penelitian ini akan menghasilkan suatu produk yang akan diimplementasikan dalam kegiatan belajar mengajar di Taman Kanak-Kanak usia 5-6 tahun guna mencapai tujuan pembelajaran yaitu memahami dan melakukan proses perilaku prososial. Penelitian ini menggunakan pendekatan penelitian gabungan dengan jenis metode penelitian dan pengembangan (research and development) dengan model ADDIE dengan lima langkah yaitu analysis, design, development, implementation, dan evaluation.

Populasi dalam penelitian ini adalah seluruh anak TK Kelompok B usia 5-6 tahun di Kota Palembang Provinsi Sumatra Selatan. Adapun langkah pemilihan sampel pada penelitian ini menggunakan teknik sampling purposive. Dipilihnya teknik sampling purposive dikarenakan pada penelitian ini akan menggunakan media komputer, akan tetapi tidak semua Taman Kanak-Kanak di Kota Palembang menyediakan fasilitas komputer. Sehingga peneliti 
memilih salah satu TK di Kota Palembang yang memiliki fasilitas komputer yaitu di TK Dharma Wanita PDAM Tirta Musi Palembang. Uji coba produk dengan game draf II dilakukan kepada enam orang anak kelompok B di TK Dharma Wanita PDAM Tirta Musi Palembang.

Gambar 1 merupakan bagan alur penelitian pengembangan media game edukasi Adventure Cooking untuk meningkatkan perilaku prososial anak usia 5-6 tahun.
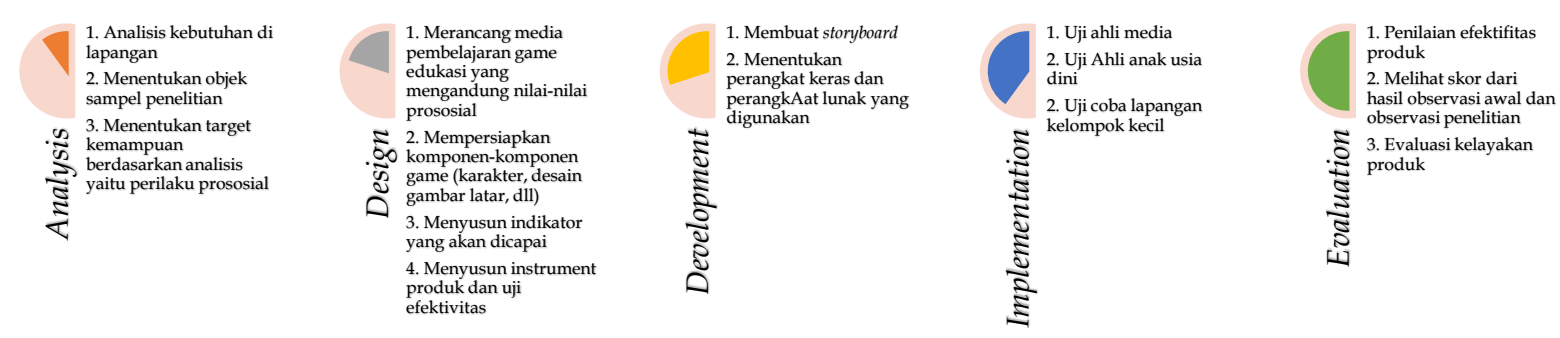

Gambar 1. Bagan Alur Penelitian

Pengumpulan data yang dilakukan dalam penelitian ini melalui evaluasi pakar, hasil uji coba kelompok kecil yang bersifat kualitatif dan kuantitatif. Data kualitatif berupa catatan, tanggapan, dan saran-saran perbaikan yang diperoleh dari hasil uji coba dan revisi. Sedangkan data kuantitatif diperoleh dari hasil distribusi lembar observasi. Analisis data selama dan sesudah di lapangan dilakukan dengan meggunakan teknik analisis data Miles dan Huberman. Data yang dianalisis secara kualitatif adalah data hasil catatan langsung oleh para ahli, data hasil refleksi anak, dan data hasil pengamatan instumen lembar observasi. Berikut ini merupakan kisi-kisi instrumen perilaku prososial.

\section{Tabel 1. Kisi-Kisi Instrumen Perilaku Prososial}

\begin{tabular}{|c|c|c|}
\hline No & Aspek & Indikator \\
\hline \multirow[t]{2}{*}{1.} & Menolong & 1. Membantu teman \\
\hline & & 2. Berbagi dalam berbagai aktivitas \\
\hline \multirow[t]{2}{*}{2.} & Empati & 1. Merasakan kondisi yang dialami orang lain \\
\hline & & 2. Menunjukkan reaksi yang sesuai dengan kondisi yang dialami orang lain \\
\hline \multirow[t]{2}{*}{3.} & Kerja sama & 1. Berinteraksi dalam kelompok \\
\hline & & 2. Bersikap kooperatif dalam kelompok \\
\hline
\end{tabular}

Adapun skala penilaian untuk lembar observasi yaitu Selalu $=4$, Sering $=3$, Kadangkadang $=2$, dan Tidak Pernah $=1$. Untuk mengetahui tingkat perkembangan perilaku prososial pada anak dilakukan penghitungan skor dengan indikator penilaian sebagai berikut: Skor 0-6 = Belum Berkembang (BB), Skor 7-12 = Masih Berkembang (MB), Skor 13-18 = Berkembang Sesuai Harapan (BSH), dan Skor 19-24 = Berkembang Sangat Baik (BSB).

Pada penelitian ini juga menggunakan analisis deskriptif kuantitatif. Analisis dilakukan terhadap tinjauan para ahli sebagai expert judgement, selain itu data kuantitatif berupa masukan dan saran juga dikelompokkan dan dianalisis lalu hasilnya digunakan untuk merevisi produk. Data kuantitatif yang diperoleh berupa hasil penyebaran angket evaluasi dari para ahli mengenai hasil produk yang dikembangkan. Tabel 2 merupakan kisi-kisi validasi ahli media. Sedangkan untuk validasi ahli pendidikan anak usia dini menggunakan kisi-kisi dapat dilihat pada tabel 3. Adapun skala penilaian yang digunakan pada instrumen evaluasi ahli media dan ahli pendidikan anak usia dini yaitu: Skor 4 = Sangat Sesuai (SS), Skor 3 = Sesuai (S), Skor 2 = Tidak Sesuai (TS), Skor 1 = Sangat Tidak Sesuai (STS). 
Tabel 2. Kisi-Kisi Validasi Ahli Media

\begin{tabular}{lrl}
\hline No & Aspek & \multicolumn{1}{c}{ Indikator } \\
\hline 1. & Tampilan & - Tampilan Media \\
& & - Ilustrasi Gambar \\
& & - Warna \\
& & - Huruf \\
2. & Penyajian & - Bahasa \\
& & - Video \\
& & - Audio \\
& & - Durasi \\
\hline
\end{tabular}

Tabel 3. Kisi-Kisi Validasi Ahli Pendidikan Anak Usia Dini

\begin{tabular}{lcl}
\hline No & Aspek & \\
\hline 1 & Tampilan & - Ilustrasi Gambar \\
& & - Bahasa \\
2 & Relevansi & - Kesesuaian media dengan karakteristik perkembangan \\
& & anak 5-6 tahun \\
& & - Kesesuaian media dengan kebutuhan perilaku prososial \\
\hline
\end{tabular}

\section{HASIL DAN PEMBAHASAN}

\section{Hasil Penelitian}

Untuk menghasilkan draf game edukasi Adventure Cooking, peneliti melakukan tahapan perencanaan dan tahap persiapan pembuatan media pembelajaran game edukasi sesuai dengan langkah pengembangan dalam model ADDIE. Analisis kebutuhan pada penelitian ini dilakukan dengan cara observasi dan wawancara kepada guru dan kepala sekolah. Hasil observasi menunjukkan bahwa pengembangan kegiatan dan media pembelajaran dalam mengembangkan perilaku prososial anak belum dilakukan secara optimal sehingga perilaku prososial anak belum berkembang sesuai dengan baik. Hasil pra observasi dapat dilihat pada gambar 2.

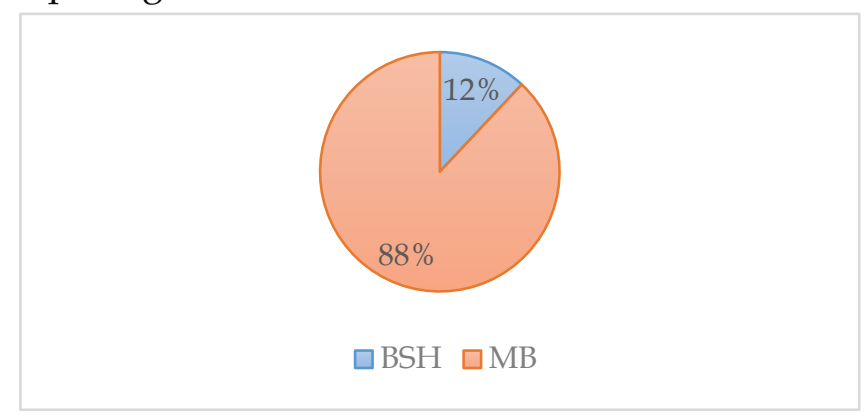

\section{Gambar 2. Diagram Hasil Pra Observasi}

Dari diagram pada gambar 2 menunjukkan bahwa dari 17 orang anak, hanya dua orang anak (12\%) yang skor perilaku prososialnya berkembang sesuai harapan (BSH), sedangkan 15 orang lainnya (88\%) masih berkembang (MB). Selain itu kegiatan pembelajaran lebih banyak dilakukan secara individu, tidak ada kegiatan pembelajaran secara berkelompok. Serta media pembelajaran yang digunakan untuk mengembangkan perilaku prososial hanya dengan menggunakan media buku cerita. Guru belum memiliki media pembelajaran khusus untuk mengenalkan perilaku prososial pada anak. Masalah ini kemudian menjadi dasar bagi peneliti untuk mengembangkan media pembelajaran yang mampu memberikan pemahaman mengenai perilaku prososial pada anak. 
Berdasarkan hasil temuan pada analisis kebutuhan, untuk merespon temuan tersebut maka perlu untuk mengembangkan dan merancang media pembelajaran berupa game edukasi yang bertujuan untuk meningkatkan perilaku prososial anak usia 5-6 tahun. Game ini diberi nama game edukasi Adventure Cooking yang dibuat dengan menggunakan aplikasi Adobe Flash versi CS6 dan dikombinasikan dengan Actionscript 3.0, sebagai aplikasi editing multimedia mulai dari membuat animasi, game sederhana, dan aplikasi media pembelajaran.

Media pembelajaran game edukasi Adventure Cooking terdiri dari lima level. Game ini akan dimainkan secara berkelompok yang terdiri dari tiga orang anak. setiap kelompok harus menyelesaikan level terendah terlebih dahulu sehingga bisa naik ke level berikutnya. Tantangan dalam setiap level game adalah membuat minuman dan makanan kesukaan keluarga dalam karakter game. Dimana setiap level anak yang sedang bermain harus mengumpulkan bahan makanan dan alat untuk membuat makanan atau minuman kesukaan keluarga. Tingkat kesulitan dalam game ini akan semakin naik dari level sebelumnya. Selain itu, game ini juga dilengkapi dengan suara alarm disela-sela permaianan pada masing-masing levelnya. Alarm ini sebagai penanda bahwa anak harus bertukar pemain, dan permainan akan dilanjutkan dengan pemain berikutnya. Gambar 3 sampai 6 merupakan tampilan dan desain awal pada game.

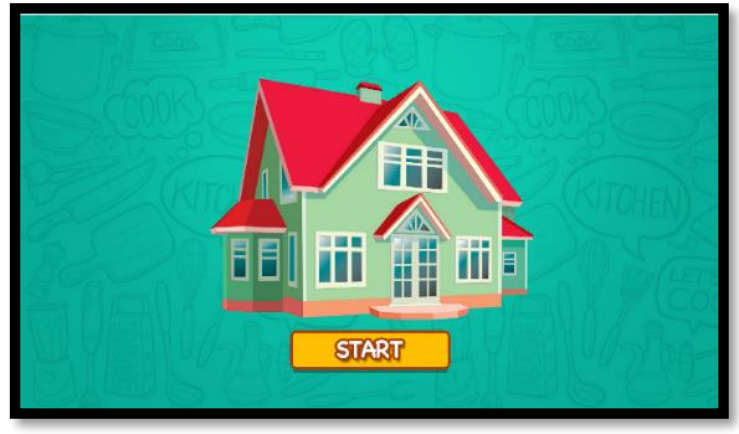

Gambar 3. Tampilan pembuka langsung start dan tidak ada tampilan dengan nama produk

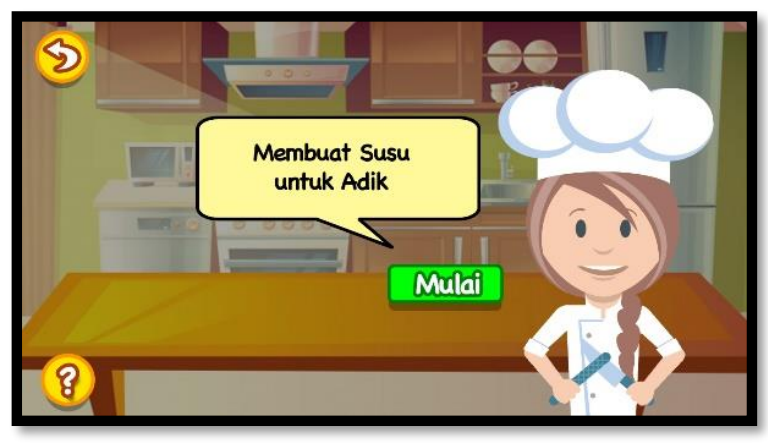

\section{Gambar 5. Karakter awal menggunakan baju chef dan Instruksi kurang jelas}

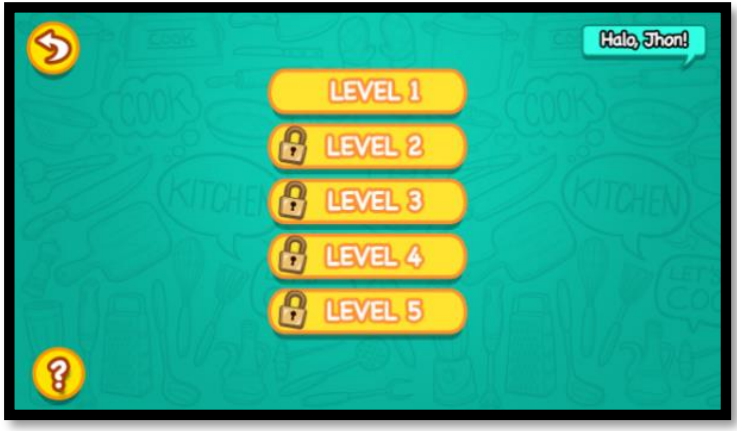

Gambar 4. Game hanya bisa dibuka sampai level 3 saja

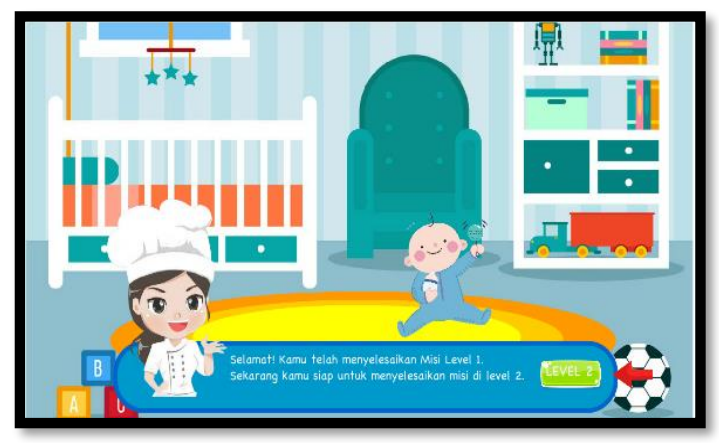

Gambar 6. Tampilan akhir di level 1 sebelum direvisi

Game yang telah dikembangkan (draf I), kemudian divalidasi oleh ahli media dan ahli anak usia dini dengan menggunakan instrumen angket. Ahli media yang melakukan validasi game edukasi Adventure Cooking adalah Bapak Muhammad Jhonse Syaftriandi, M.Kom selaku dosen di Sekolah Tinggi Manajemen dan Ilmu Komputer Palcomtech Palembang. Berikut ini adalah hasil rekapitulasi validasi ahli media terhadap game edukasi Adventure Cooking.

Berdasarkan tabel 4, mengenai hasil penilaian ahli media terhadap game edukasi Adventure Cooking diperoleh skor rata-rata 3,5 (BAIK). Hasil ini menunjukkan bahwa game edukasi Adventure Cooking dari segi media meliputi tampilan dan penyajian yang digunakan 
telah baik. Ahli pendidikan anak usia dini yang melakukan validasi pada game edukasi Adventure Cooking adalah Ibu Dr. Sri Wulan, M.Si selaku dosen PAUD FIP Universitas Negeri Jakarta, dan Ibu Peninna Sinambela, S.Pd selaku guru kelas dan komputer di TK Dharma Wanita PDAM Tirta Musi Palembang. Berikut ini adalah hasil rekapitulasi validasi ahli pendidikan anak usia dini terhadap game edukasi Adventure Cooking.

Tabel 4 Penilaian Ahli Media

\begin{tabular}{ll}
\hline Komponen & Penilaian \\
\hline $1 . \quad$ Tampilan & 3,4 \\
2. Penyajian & 3,6 \\
\hline Rata-Rata & $\mathbf{3 , 5}$ (BAIK) \\
\hline
\end{tabular}

Tabel 5. Penilaian Ahli Anak Usia Dini

\begin{tabular}{lll}
\hline Komponen & Ahli AUD 1 & Ahli AUD 2 \\
\hline 1. Tampilan & 3 & 3,5 \\
2. Relevansi & 2,8 & 3,8 \\
\hline Rata-rata & $\mathbf{2 , 9}$ (CUKUP) & $\mathbf{3 , 6 5}$ (BAIK) \\
Rata-rata keseluruhan & $\mathbf{3 , 2}$ (BAIK) & \\
\hline
\end{tabular}

Berdasarkan tabel 5 mengenai hasil penilaian ahli anak usia dini terhadap game edukasi Adventure Cooking diperoleh skor rata-rata 3,2 (BAIK). Hasil ini menunjukkan bahwa dari edukasi Adventure Cooking dari segi pendidikan anak usia dini meliputi tampilan dan relevansi yang digunakan telah baik. Berdasarkan hasil uji telaah dari tiga orang pakar, maka diperoleh beberapa saran dan masukan terhadap game edukasi Adventure Cooking. Kemudian game di revisi dan diperbaiki sesuai masukan dari para pakar atau ahli. Gambar 7 sampai 10 merupakan tampilan game setelah mendapat masukan dari para ahli.

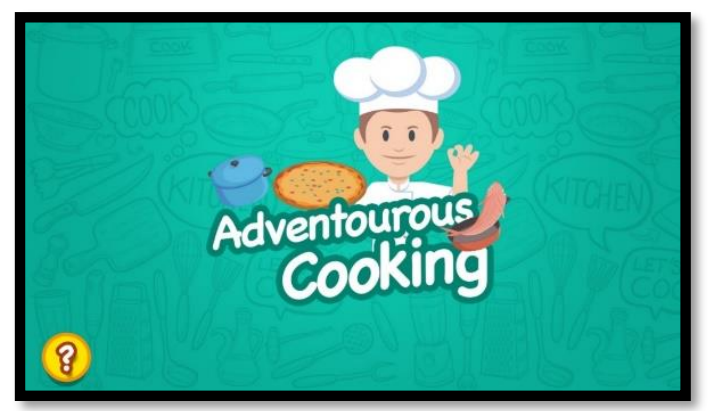

Gambar 7. Ditambah gambar tampilan pembuka

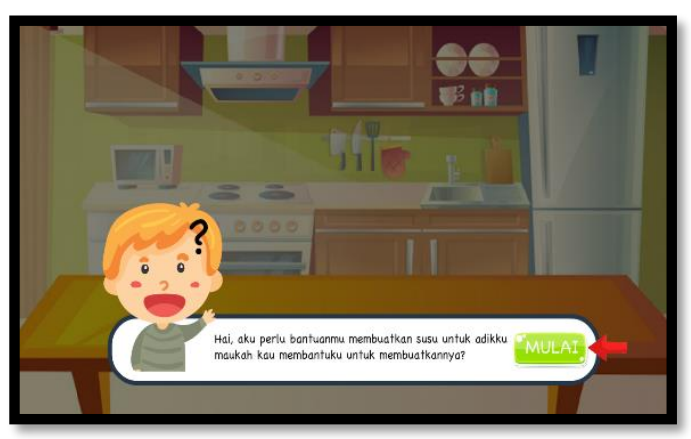

Gambar 9. Karakter dirubah menjadi karakter anak dengan instruksi yang jelas

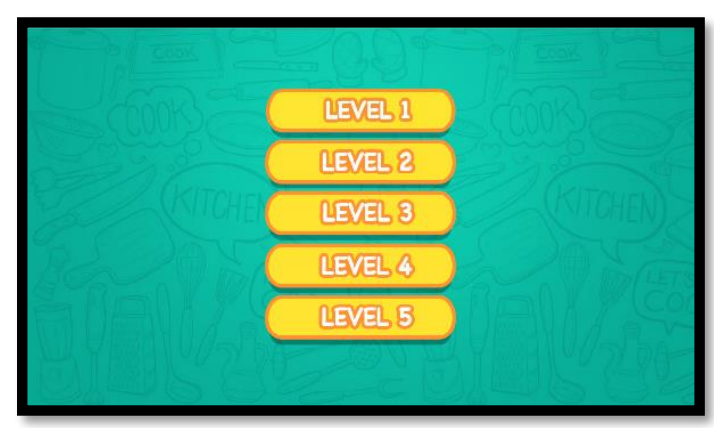

Gambar 8. Game sudah bisa digunakan sampai level 5

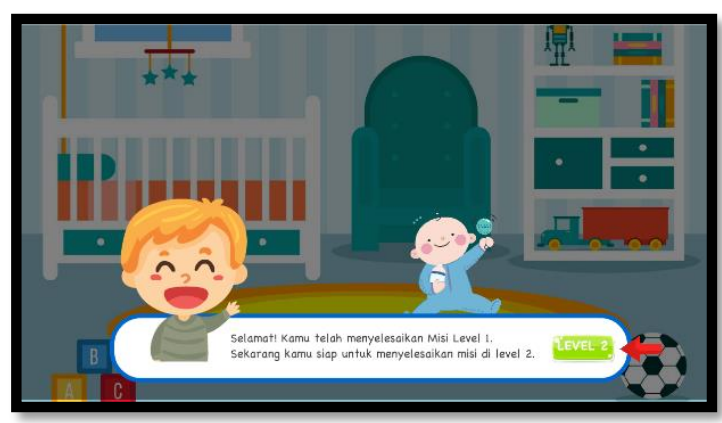

Gambar 10. Tampilan akhir di level 1 sesudah direvisi 
Media game edukasi Adventure Cooking direvisi kembali dan dikembangkan menjadi game draft 2. Hal ini dilakukan berdasarkan saran dan masukan dari para ahli. Selanjutnya game draft 2 diujicobakan pada anak usia 5-6 tahun sebanyak enam orang anak yang terdiri dari dua orang anak laki-laki dan empat orang anak perempuan di TK Dharma Wanita PDAM Tirta Musi Palembang. Penelitian ini hanya dilakukan pada beberapa anak saja, tidak sampai uji coba lapangan utama. Hal ini dikarenakan adanya pandemi Covid 19, sehingga sekolah diliburkan dan tidak bisa dilakukan uji coba lapangan utama.

Evaluasi dilakukan dengan uji kelayakan secara teoritik dan uji efektivitas. Berikut ini uji teoritik dan uji efektivitas. Kelayakan media ini secara teoritik dapat dibuktikan dengan validasi oleh para ahli. Validasi ahli merupakan penilaian yang dilakukan oleh ahli untuk menilai sejauhmana media ini dapat memenuhi syarat dari berbagai aspek pengembangan. Pada penelitian ini, media divalidasi oleh para ahli di bidang Pendidikan anak usia dini dan media pembelajaran. Tabel 6 merupakan tabel hasil uji ahli.

Tabel 6. Hasil Uji Ahli

\begin{tabular}{llll}
\hline No & Ahli & Nilai Rata-Rata & Kriteria \\
\hline 1. & Ahli Media & 3,5 & BAIK \\
2. & Ahli Pendidikan Anak Usia Dini & 3,2 & BAIK \\
\hline
\end{tabular}

Berdasarkan data tabel 6, dapat disimpulkan bahwa media game edukasi game Adventure Cooking untuk meningkatkan perilaku prososial anak baik untuk digunakan. Uji efektivitas media bertujuan untuk melihat keefektifan media game edukasi game Adventure Cooking untuk meningkatkan perilaku prososial anak. Hasil pengembangan draft 2 menghasilkan produk media yang digunakan sebagai media untuk menguji keefektifan media. Uji efektivitas dilakukan di TK Dharma Wanita PDAM Tirta Musi Palembang dengan jumlah responden sebanyak 6 orang anak. Berikut adalah skor observasi awal dan observasi penelitian dapat dilihat pada tabel yang telah disajikan pada tabel 7.

Tabel 7. Hasil Observasi Awal dan Observasi Penelitian

\begin{tabular}{|c|c|c|c|c|c|c|}
\hline \multirow{4}{*}{$\begin{array}{l}\text { RESPO } \\
\text { NDEN }\end{array}$} & \multicolumn{4}{|c|}{ PENILAIAN } & \multirow{4}{*}{$\begin{array}{c}\text { Peningkatan } \\
(\%)\end{array}$} & \multirow[t]{4}{*}{ Keterangan } \\
\hline & \multicolumn{2}{|c|}{ Observasi Awal } & \multicolumn{2}{|c|}{ Observasi Penelitian } & & \\
\hline & Total & Persentase & Total & Persentase & & \\
\hline & Skor & & Skor & & & \\
\hline $\mathbf{A}$ & 35 & $48,6 \%$ & 59 & $81,9 \%$ & $33,3 \%$ & Ada Peningkatan \\
\hline $\mathrm{C}$ & 40 & $55,5 \%$ & 67 & $93 \%$ & $37,5 \%$ & Ada Peningkatan \\
\hline $\mathbf{E}$ & 37 & $51,4 \%$ & 59 & $81,9 \%$ & $30,5 \%$ & Ada Peningkatan \\
\hline $\mathbf{N}$ & 33 & $45,8 \%$ & 55 & $76,4 \%$ & $30,6 \%$ & Ada Peningkatan \\
\hline $\mathbf{T}$ & 35 & $48,6 \%$ & 56 & $77,7 \%$ & $29,1 \%$ & Ada Peningkatan \\
\hline $\mathbf{Y}$ & 33 & $45,8 \%$ & 52 & $72,2 \%$ & $26,4 \%$ & Ada Peningkatan \\
\hline $\begin{array}{l}\text { RATA- } \\
\text { RATA }\end{array}$ & 35,5 & $49,3 \%$ & 58 & $71,5 \%$ & $31,2 \%$ & Ada Peningkatan \\
\hline
\end{tabular}

Berdasarkan hasil pada tabel 7, rata-rata nilai observasi awal menunjukkan nilai 35,5 dengan persentase $49,3 \%$. Kemudian rata-rata nilai observasi penelitian menunjukkan 58 dengan persentase $71,5 \%$. Hasil skor observasi awal dan observasi penelitian menunjukkan bahwa terdapat perbedaan persentase peningkatan sebesar 31,2\%. Hal ini berarti bahwa media game edukasi game Adventure Cooking dapat diterima sebagai salah satu media yang dapat digunakan untuk meningkatkan perilaku prososial.

\section{Pembahasan}

Penelitian dan pengembangan media game edukasi Adventure Cooking untuk meningkatkan perilaku prososial anak dilakukan karena kurangnya media untuk membantu 
anak dalam mengembangkan perilaku prososial. Hal ini sesuai dengan hasil observasi sebelum penelitian yang disimpulkan bahwa untuk meningkatkan perilaku prososial anak di sekolah hanya melalui media buku cerita saja. Sehingga peneliti berinisiatif untuk membuat suatu media game yang dapat meningkatkan perilaku prososial anak. Game ini mengangkat tema keluarga, dimana dalam setiap level game ini pemain harus menyelesaikan misi untuk membuat makanan kesukaan keluarga yaitu adik, kakak, ayah, ibu, kakek dan nenek. Tema ini dipilih karena keluarga adalah orang terdekat anak. Perilaku prososial yang akan terbentuk nanti tidak hanya dilakukan anak saat bermain game dengan temannya di sekolah saja, namun juga dapat diaplikasikan anak saat anak berada di rumah. Hal ini didukung dengan pendapat Matondang (2016) yang mengatakan bahwa faktor-faktor lain yang mempengaruhi timbulnya perilaku prososial anak adalah bawaan dari rumah, yaitu orang tua berupaya membentuk perilaku prososial anak dalam kegiatan sehari-hari. Jika prososial tersebut sudah mampu diaplikasikan anak pada keluarga, maka akan lebih mudah bagi anak untuk mengaplikasikannya di lingkungan lainnya.

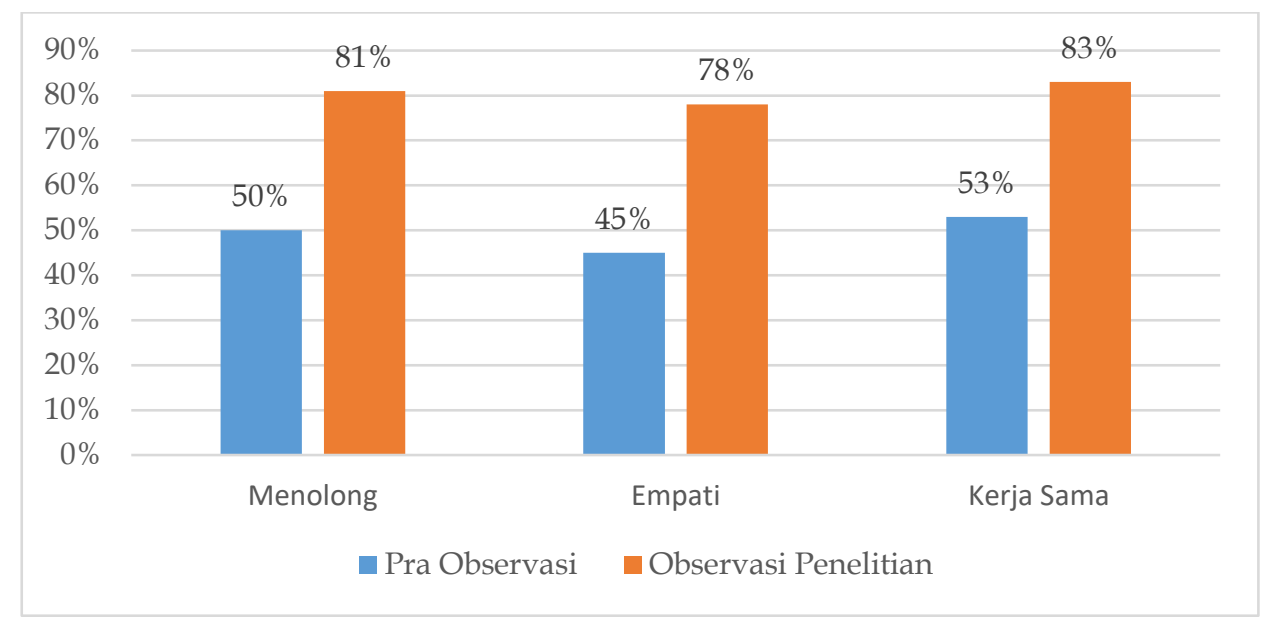

\section{Gambar 11. Grafik Peningkatan Perilaku Prososial Anak dalam Aspek Menolong, Empati dan Kerjasama}

Tujuan utama dibuatnya game edukasi Adventure Cooking adalah untuk meningkatkan perilaku prososial anak. Pada saat anak memainkan game Adventure Cooking secara bersamaan mereka telah mengembangkan perilaku prososialnya dengan aspek menolong, empati dan kerja sama. Gambar 11 adalah grafik peningkatan perilaku prososial anak.

Grafik pada gambar 11 menunjukkan terjadi peningkatan pada aspek menolong sebesar 31\%, aspek empati sebesar 33\%, dan aspek kerjasama sebesar 30\%. Pada aspek menolong terlihat saat anak memberikan bantuan pada teman satu kelompok mereka dengan cara memberikan petunjuk-petunjuk saat teman satu kelompok mereka kesulitan dalam mencari alat/bahan untuk memasak di dalam game tersebut. Menurut Clarke perilaku menolong merupakan sebuah bagian dari perilaku prososial yang dipandang sebagai segala sesuatu tindakan yang diarahkan untuk memberikan keuntungan kepada orang lain (Clarke, 1987; Fitriyana dkk., 2019). Tindakan menolong yang dilakukan dengan kerelaan hati, yang dipikirkan hanyalah bagaimana orang yang ditolong dapat menyelesaikan permasalahan yang sedang dihadapi merupakan salah satu wujud perilaku prososial (Bashori, 2017).

Untuk aspek empati terlihat saat anak dapat merasakan kondisi yang dialami temannya, misalnya saat temannya bermain anak yang lain memberikan dukungan dan semangat. Selain itu anak-anak tidak saling menyalahkan saat kelompok mereka kalah. Kelompok yang menangpun tidak mengejek kelompok yang kalah. Kondisi emosi berupa empati menjadi penyebab dari munculnya perilaku prososial, dimana seseorang merasakan 
apa yang dirasakan orang lain seperti dia mengalaminya sendiri, dan apa yang dirasakannya sesuai dengan perasaan dan kondisi orang yang bersangkutan (Kau, 2017).

Selanjutnya untuk aspek kerjasama terlihat saat anak mendiskusikan bersama apa nama kelompok mereka dan mendiskusikan bersama urutan pemain pertama, kedua dan ketiga. Selain itu terlihat dari kekompakan anak saat memainkan game tersebut, anak mampu bekerja dalam tim demi menyelesaikan level demi level dalam game. Hal ini sesuai dengan teori Partern (Santrock, 2002; Fauziddin, 2016) yang menyatakan bahwa anak usia prasekolah dan pada masa pertengahan anak sudah berada pada tahapan cooperative play atau bermain secara kelompok dan kerja sama. Terlihat saat anak mampu bekerjasama, berbagi tugas serta pembagian peran antara anak-anak yang terlibat dalam permainan. Selain itu, penelitian yang dilakukan oleh Muchtar dkk., (2018) menyatakan bahwa pola permainan cooperative play merupakan pola permainan yang paling efektif untuk menstimulasi kompetensi konsep diri, kemampan mengelola emosi, sosial akademik, dan perilaku prososial. Pangrazi dan Dauer (Pangrazi dan Duer, 1986; Grineski, 2018) juga berpendapat bahwa permainan berkelompok memberikan tingkat interaksi yang tinggi bagi anak-anak, sehingga perilaku prososial pasti terjadi.

Saat anak bermain game edukasi Adventure Cooking, anak terlihat aktif berinteraksi dengan teman-temanya. Anak mendiskusikan siapa yang akan menjadi pemain pertama, kedua dan ketiga. Anak juga bediskusi untuk menentukan apa nama kelompok mereka. Anak juga belajar untuk mendengarkan pendapat temanya. Interaksi seperti ini dapat meningkatkan perilaku prososial anak. Sependapat dengan yang dikatakan Bashori (2017) bahwa interaksi kolaboratif dengan teman sebaya diyakini dapat memotivasi pengembangan keterampilan kognitif yang mendukung terbentuknya perilaku prososial. Permainan dapat berdampak pada perkembangan perilaku sosial pada anak, dampaknya ada yang positif dan ada yang negatif, dan tergantung pada struktur permainan (Grineski, 2018). Media game edukasi Adventure Cooking dapat membantu guru untuk mengajarkan perilaku prososial. Sehingga dalam pengembangan perilaku prososial di sekolah tidak monoton, seperti yang selama ini dimana perilaku prososial hanya diajarkan melalui media buku cerita dan pembiasaan saja.

\section{SIMPULAN}

Media game edukasi Adventure Cooking terbukti efektif dalam meningkatkan perilaku prososial anak usia 5-6 tahun. Hal ini dapat terlihat dari adanya peningkatan hasil pra observasi dan observasi penelitian dengan nilai peningkatan rata-rata sebesar $31 \%$ dalam aspek menolong, empati, dan kerjasama setelah anak bermain media game edukasi Adventure Cooking. Hambatan dalam penelitian ini adalah penelitian tidak sampai uji coba lapangan utama dikarenakan adanya pandemi Covid 19, sehingga sekolah diliburkan. Selain itu, tidak semua sekolah memiliki komputer untuk anak, sehingga game ini hanya dapat diterapkan pada beberapa sekolah yang memang memiliki fasilitas ruang komputer untuk anak.

\section{UCAPAN TERIMA KASIH}

Terima kasih penulis ucapkan kepada Ketua Yayasan, kepala sekolah serta guru di TK Dharma Wanita PDAM Tirta Musi Palembang yang telah memberikan kesempatan kepada penulis untuk melakukan penelitian. Kepada editorial dan reviewer Jurnal Obsesi yang sudah memberikan kesempatan sehingga jurnal ini siap untuk diterbitkan. Untuk dosen-dosen di Universitas Negeri Jakarta terutama dosen pembimbing ibu Phil. Zarina Akbar dan ibu Dr. Yuliani Nurani, M.Pd yang telah memberikan semangat dalam penulisan ini sehingga penulis dapat menyelesaikan tepat pada waktunya 


\section{DAFTAR PUSTAKA}

Aeni, W. A. (2009). Antara Game, Pendidikan dan HP (Game Mobile Learning Sebagai Wacana Pendidikan). Retrieved from https://medukasi.kemdikbud.go.id/medukasi/?m1=artikel\&kd=3

Anggraini, A. F., Erviana, N., Anggraini, S., \& Prasetya, D. D. (2016). Aplikasi Game Edukasi Petualangan Nusantara. SENTIA, 8(2085-2347), 168-172.

Arsyad, A. (2014). Media Pembelajaran. Jakarta: Rajagrafindo Persada.

Bashori, K. (2017). Menyemai Perilaku Prososial di Sekolah. Sukma: Jurnal Pendidikan, 1(1), 57-92. Retrieved from https://jurnalsukma.org/index.php/sukma/article/view/01103.2017/10 https://doi.org/10.32533/01103.2017

Basri, H. (2015). Paradigma Baru Sistem Pembelajaran. Bandung: Pustaka Setia.

Chagas, C. M. dos S., Silva, T. B. P. e, Reffatti, L. M., Botelho, R. B. A., \& Toral, N. (2018). Rango Cards , A Digital Game Designed To Promote A Healthy Diet: A Randomized Study Protocol. BMC Public Health, 11-13. https:// doi.org/10.1186/s12889-018-5848-0

Drupadi, R., Palupi, W., \& Karsono. (2014). Pengaruh Teks Lagu Anak-Anak Terhadap Perilaku Prososial Anak TK. Universitas Sebelas Maret, 1-8.

Eisenberg, N., Spinrad, T. L., \& Knafo-Noam, A. (2015). Handbook of Child Psychology and Developmental Science Chapter 15. (M. E. Lamb \& R. M. Lerner, Eds.) (7th Editio). Canada: Wiley. https:// doi.org/10.1002/9781118963418.childpsy315

Fauziddin, M. (2016). Peningkatan Kemampuan Kerja Sama melalui Kegiatan Kerja Kelompok Pada Anak Kelompok A TK Kartika Salo Kabupaten Kampar. JURNAL PAUD TAMBUSAI, 2, 29-45. Retrieved from http://journal.stkiptam.ac.id/index.php/obsesi https:// doi.org/10.31004/obsesi.v2i1.47

Fitriyana, R., Zwagery, R. V., \& Safitri, J. (2019). Perbedaan Perilaku Menolong Pada Anak Usia Dini Yang Diberikan Cerita Moral Yang Menekankan Emosi Negatif Pengamat Dengan Cerita Nonmoral Di Paud Idaman Banjarbaru. Kognisia, 2, 95-101. Retrieved from http://ppjp.ulm.ac.id/journals/index.php/kog/article/view/1672/1323

Goleman, D. (2018). Emotional Intelligence Kecerdasan Emosional. Jakarta: Gramedia Pustaka Utama.

Grineski, S. (2018). Children, Games, and Prosocial Behavior-Insight and Connections. Journal of Physical Education, Recreation \& Dance, 60(8), 20-25. https:// doi.org/10.1080/07303084.1989.10606373

Herminastiti, R. (2019). Peran Kegiatan Fun Cooking dan Country Project dalam Kemampuan Matematika Awal dan Berpikir Kritis Anak Usia Dini. KINDERGARTEN: Journal of Islamic Early Childhood Education, 2(1), 6-14. https:// doi.org/10.24014/kjiece.v2i1.6993

Hong, J.-C., Cheng, C.-L., Hwang, M.-Y., Lee, C.-K., \& Chang, H.-Y. (2009). Assessing The Educational Values of Digital Games. Journal of Computer Assisted Learning, 25, $423-$ 437. https://doi.org/10.1111/j.1365-2729.2009.00319.x

Hong, J.-C., Tsai, C.-M., Ho, Y.-J., Hwang, M.-Y., \& Wu, C.-J. (2014). A Comparative Study of the Learning Effectiveness of a Blended and Embodied Interactive Video Game for Kindergarten Students. Routledge Taylor \& Francis Group, 21(1), 39-53. https:// doi.org/10.1080/10494820.2010.542760

Kau, M. A. (2017). Empati dan Perilaku Prososial pada Anak. Inovasi, 7(3), 1-5.

Kostelnik, M. J., Gregory, K. M., Soderman, A. K., \& Whiren, A. P. (2012). Guiding Children's Social Development and Learning (Seventh Ed). United States of America: Wadsworth Cengage Learni.

Maswan, \& Muslimin, K. (2017). Teknologi Pendidikan Penerapan Pembelajaran yang Sistematis. Yogyakarta: Pustaka Pelajar. 
Matondang, E. S. (2016). Perilaku Prososial (Prosocial Behavior) Anak Usia Dini Dan Pengelolaan Kelas Melalui Pengelompokan Usia Rangkap (Multiage Grouping). Jurnal Pendidikan Dasar, 8(1). https://doi.org/10.17509/eh.v8i1.5120

Mirawati, Nurkamilah, M., \& Anggarasari, N. H. (2018). Fun Cooking: Pembelajaran Matematika yang Menyenangkan Bagi Anak Usia Dini. Jurnal Pendidikan: Early Childhood, 2(1), 1-6. https:// doi.org/10.35568/earlychildhood.v2i1.230

Mubarok, R. (2018). Pengembangan Game Edukasi Ayo Memasak Bersama di RA Amanah Berbasis Android Untuk Anak Usia Dini. Universitas Negeri Jakarta.

Muchtar, H. S., Indalika, A., \& Razak, M. (2018). Bermain Sebagai Intervensi Untuk Meningkatkan Kompetensi Sosial Anak, 12(November), 241-250. https://doi.org/10.21009/JPUD.122

Rifqiana, W., Anwar, S., Hernawan, H., \& Safitri, E. R. (2018). Penerapan Cai Model "Game Petualangan" Dalam Meningkatkan Minat Dan Hasil Belajar Pada Pembelajaran Sejarah Kebudayaan Islam. Jurnal Teknologi Pendidikan Dan Pembelajaran, 3, 713-725. https://doi.org/10.31980/tp.v3i2.426

Schell, J. (2008). The Art of Game Design: A Book of Lenses. United States of America: Morgan Kufmann Publishers. https://doi.org/10.1201/9780080919171

Sette, S., Colasante, T., Zava, F., Baumgartner, E., \& Malti, T. (2018). Preschoolers ' Anticipation of Sadness for Excluded Peer, Sympaty, and Prosocial Behavior. The Journal of Genetic Psychology, 1-11. https://doi.org/10.1080/00221325.2018.1502147

Spivak, A. L., \& Farran, D. C. (2012). First-Grade Teacher Behaviors and Children's Prosocial Actions in Classrooms. Early Education \& Development, 9289. https://doi.org/10.1080/10409289.2011.566164

Syahrizal, S., \& Putri, E. D. H. (2014). Usaha Pengelolaan Makanan Untuk Meningkatkan Kualitas Makanan Di Warung Makan Ulegfood Bantul. Jurnal Khasanah Ilmu, V(1), 69-75.

Thijssen, S., Wildeboer, A., Muetzel, R. L., Bakermans-, M. J., Marroun, H. El, Hofman, A., ... White, T. (2015). Cortical Thickness and Prosocial Behavior In School-Age Children: A Population-Based MRI Study. Routledge Taylor \& Francis Group, 10(6), 571-582. https:// doi.org/10.1080/17470919.2015.1014063

Woods, H., Bosacki, S., \& Coplan, R. J. (2016). Canadian Early-Childhood Educators' Perceptions of Children's Gendered Shy, Aggressive, and Prosocial Behaviors Canadian. Journal of Research in Childhood Education, 30(3), 320-333. https://doi.org/10.1080/02568543.2016.1178199 